\title{
AN ANALYSIS OF COHERENCE AND COHESION ON THE STUDENTS' DESCRIPTIVE WRITING AT SENIOR HIGH SCHOOL IN CIREBON
}

\author{
Siti Wahyuni ${ }^{1}$ \\ SMA Kartika XIX-5, Cirebon \\ Universitas Indpraprasta PGRI, Jakarta \\ Oom Rohmah ${ }^{2}$ \\ Postgraduate Faculty, Universitas Indraprasta PGRI, Jakarta \\ e-mail: swahyuni46044@ gmail.com ${ }^{1}$ \\ e-mail: oom.rohmah@ unindra.ac.id 2
}

\begin{abstract}
This study aimed to find out the usage of coherence and cohesion on the Students' Descriptive Texts, especially in ten grader students at state senior high school in Cirebon. This study adopted thematic progression analysis to explore coherence in the students' Descriptive text. This study was a qualitative study that used content analysis. The technique of collecting data was documentation from 46 students writing descriptive texts. The procedures were firstly collecting data, analyzing data, presenting data, and concluding the result of the study. Based on the analyzed data,1) 46 students' writing descriptive text had grown the writing as the series of the stage in the descriptive text, using Identification and Description. Then, in analyzing coherence 2) $76 \%$ students got the coherence level is good, there are 19\% in Fair, there are 2\% in Less and 3\% in Poor and in analyzing cohesion 3) there are 1052 cohesion markers that consist of 852 findings markers of grammatical cohesion (596 findings markers reference and 256 markers conjunction) and 200 markers of lexical cohesion (200 markers repetition).
\end{abstract}

Keyword: series of stage, coherence, cohesion

\section{Introduction}

In the 21st century, English has become one of the most used languages globally. Many people speak English. There are more than fifty countries that use English as their official language. Because of spreading English worldwide, there are several benefits of mastering English. First, everyone can show their talent to the world through 21st-century technology or the Internet. It is because English is the Top language of the Internet. They use English to communicate with others all over the world. Besides, English is also a tool to tell our ideas and spread our thinking in writing. Many books are written using English. The original definition of language based on Sapir (1921) said that language is a purely human and noninstinctive method that produces symbols voluntarily to communicate ideas, emotions, and desires. It clearly explains that language can communicate ideas using spoken or written expression. As well as technology development grows, it is a must that everyone should have spoken and writing skills.

There are four skills to be mastered in English: meaning-focused input - listening-reading and meaning-focused output - speaking-writing. One of the significant areas or a must-have skill in the $21^{\text {st }}$ century is writing. Many people write books, but few people cannot continue their writing because of stuck to delivering their ideas in a paragraph. Because in writing, it connects sentence by sentence and paragraph to each context of the situation. Thus, people must have well-developed critical thinking skills before writing a word or reading to make a readable paragraph.

Although the writers should pay attention to well-developed critical thinking, many English foreign and second language teachers are concerned about teaching writing conventionally and emphasize grammatical accuracy only (Broughton et al., 2003, p. 118). They do not know that the context of the text is essential. The context of the situation in the text is coherence. It means that the text lies within the context 


\section{INFERENCE: Journal of English Language Teaching}

Vol. 4, No. 3, December 2021 - March 2022

p-ISSN: 2615-8671

e-ISSN: 2615-868X

so that the readers hold a text as a unified composition and consists of grammatical units that support the ideas as a whole passage (Tanskanen, 2006: p.7). Its grammatical unit is a cohesive device divided into two-part, grammatical cohesion and lexical cohesion. Those devices make a text a unified whole by connecting the sentence to another sentence, so the reader read the passage smoothly from one to another.

Many schools design various topics and kinds of genres in teaching English. Genre is like a type of text provided in a school syllabus to make students familiar in the series of the stage on the kind of text it is as Schleppegrell (2004:82) said that genre is a term used to refer to a particular text or discourse types. Narrative, descriptive, procedure, report, exposition, and soon. Those texts have their purpose. Descriptive text is a kind of text that describes someone, something, and somewhere. It should be hanging together to make that writing comprehensible. Students should pay attention to the use of coherence and cohesion. This issue is fundamental whether how long the student's skill in using these devices. In a broader context, the researcher should make a framework before investigating to clarify what they want to do. The researcher also needs many theories to support their idea and overview how this study has been examined in several countries and institutions.

The other research examines the cohesion and coherence of students' descriptive writing of undergraduate thesis the fourth students in IAIN Salatiga (Ma'rifatullah, 2016). This study comes from Andayani, who states that students still have problems using cohesion and coherence in their English Narrative text. Concerning this, the researcher wants to investigate whether the students writing hang together with the context or the grammar entitled "An Analysis on Coherence and Cohesion Of Students Descriptive Writing At State Senior High School In Cirebon" Then the research formulation will be as follow:

1. How do the students compose their writing descriptive based on the stage series in the descriptive text?

2. What kind of coherence is found in the texts?

3. What kind of cohesion is found in the descriptive text?

\section{Method}

The research design is discourse analysis; this kind of research is used when the researcher wants to investigate and examine the written and spoken document. The researcher wants to examine coherence and cohesion in the students' descriptive writing at state senior high school, especially 46 students' writing in Cirebon. As given, et al. (2008) said that discourse analysis studies language use in society expressed by conversation or documentations.

This research will be qualitative in analyzing the using coherence and cohesion in the students' descriptive writing. Djam'an (2011:23) stated that qualitative research examines the phenomena that cannot be occurred in quantitative research. Because this study analyzes the content of the text that is cohesion and coherence, the specific design of this research is content analysis. Based on Ary (2010: 29), the content analysis focuses on analyzing and interpreting recorder material to learn about human behavior, and material may be public records, textbooks, letters, films, tapes, diaries, themes, reports, and other documents. The framework of this research will be as below:

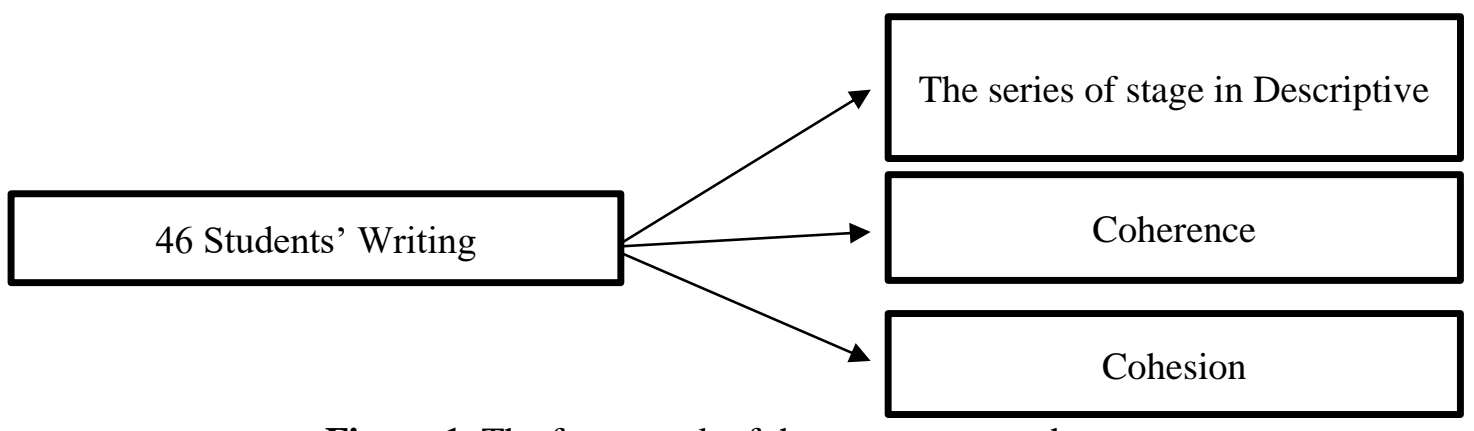

Figure 1. The framework of the current research 


\section{Population and Sample}

The object of this research will be the tenth-grade students' descriptive writing at the two-state senior high school in Cirebon. There will be 460 students' descriptive writing there, but the researcher took 46 students' descriptive writing samples of the 460 population. This 46 students' descriptive writing will investigate the category of coherence, cohesion, and the series of stages whether they use the series of descriptive text.

\section{Result and Discussions}

There are about 46 texts from two schools in Cirebon. The researcher collected the data from tenthgrade students at senior high school. The researcher examined whether the students' descriptive texts are appropriate with the stage series in descriptive text. The structure or the stage series in the descriptive text are Identification or Classification and Description.

\section{The result of analyzing the series of the stage in the Students' Descriptive writing} follow:

The result of analyzing the series of the stage in the Students' Descriptive writing is presented as

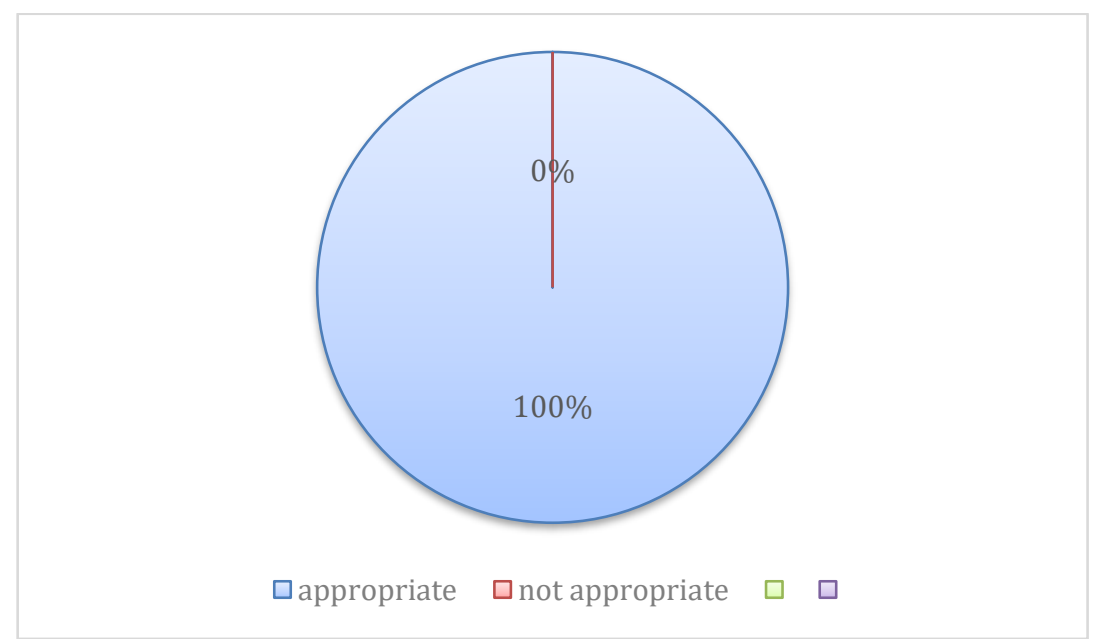

Figure 2. The series of stages found in the text

The 46 students' descriptive writing sample is appropriate to the stage series based on the chart above. It means that the students can arrange Descriptive writing and their structure or appropriate to the stage series. Those are writing consist of Identification and Description. An example of the analysis is shown below:

Table 1. Students 01

\begin{tabular}{|l|l|}
\hline \multicolumn{1}{|c|}{ Identification } & \multicolumn{1}{c|}{ Description } \\
\hline Mr. Bean is a \\
$\begin{array}{l}\text { comedy TV show } \\
\text { played by Rowan } \\
\text { Atkinson. }\end{array}$ & $\begin{array}{l}\text { When he becomes Mr. Bean, he always wears brown suit and treausers, white shirt, a thin } \\
\text { green mini cooper, and bring his teddy bear everywhere. Even though at Mr. Bean movie, } \\
\text { he always makes a problem that make some people...................., everyone still like } \\
\text { him. }\end{array}$ \\
\hline
\end{tabular}

Table 1 shows that the students' descriptive writing has been used in the stage series. The beginning of the descriptive text above is Mr. Bean, a comedy TV show played by Rowan Atkinson, and ending with describing Mr. Bean's clothes by the sentence he always wears brown suit and treausers, white shirt, a thin red tie, and black shoes. Nevertheless, something is missing from that. It is because the student forgets the word to express. It could be the word 'angry.' 


\section{INFERENCE: Journal of English Language Teaching}

Vol. 4, No. 3, December 2021 - March 2022

p-ISSN: 2615-8671

e-ISSN: 2615-868X

\section{The Result of Analysing Coherence}

There is four-level of coherence: Good, Fair, Less, and Poor. Regarding analyzing the data of 46 students' writing, the researcher examined those writing using SFL (Systemic Functional Linguistic), analyzing especially thematic progression. Firstly, the researcher broke the sentence into a clause and analyzed the part of the clause into a table such as shown in Table 2:

Table 2. Three Lines of Meaning

\begin{tabular}{|c|c|c|c|}
\hline $\begin{array}{c}\text { Three lines of } \\
\text { meaning }\end{array}$ & Mr Bean & Is & A comedy TV show \\
\hline Exp= F & Carrier & Pr. Intensive & Attribute \\
\hline Int= T & Subject & Finite & Complement \\
\cline { 2 - 4 } & THEME MOOD & RESIDUE \\
\hline Tex= M & RHEME \\
\hline
\end{tabular}

Three meaning lines mean three major analyses in this section: Field, Tenor, and Mode. The researcher encoded Field as exp (experiential), Tenor as int (Interpersonal), and Mode as Tex (Textual). In this analysis, the researcher broke down the clause into parts, like in the example above that Mr. Bean is as Carrier, Intensive process and attribute in experiential part, and as subject, finite and complement in interpersonal part. The word $M r$. Bean is is as MOOD, and a comedy TV show is as RESIDUE. While in the textual Mode, the word Mr. Bean is being Theme, and the word is a comedy TV show is as Rheme. The primary information in the SFL analysis above is $M r$. Bean as the leading actor in the sentence above. The result of analyzing coherence as in the following:

Table 3. Coherence Levels \& Types of Process

\begin{tabular}{|c|c|c|c|c|c|c|c|c|}
\hline \multirow[b]{2}{*}{ Student } & \multicolumn{7}{|c|}{ Type of Process } & \multirow[b]{2}{*}{$\begin{array}{c}\text { Coherence } \\
\text { level }\end{array}$} \\
\hline & Intensive & $\begin{array}{l}\text { Existenti } \\
\text { al }\end{array}$ & Material & Possession & Mental & $\begin{array}{c}\text { Behaviora } \\
1\end{array}$ & Verbal & \\
\hline 01 & 2 & & 6 & 2 & 1 & & & Fair \\
\hline 02 & 3 & & 7 & 3 & 1 & 2 & & Good \\
\hline 03 & 5 & & 7 & 1 & & & 1 & Good \\
\hline 04 & 3 & & 5 & 2 & & 4 & & Good \\
\hline 05 & 6 & & 8 & & 1 & & & Good \\
\hline 06 & 3 & & 2 & 5 & & & & Good \\
\hline 07 & 5 & & 8 & 2 & 2 & & & Fair \\
\hline 08 & 7 & & 4 & 4 & 2 & & & Good \\
\hline 09 & 6 & 1 & 3 & 3 & & & 1 & Good \\
\hline 10 & 4 & & 6 & 2 & 1 & & & Good \\
\hline 11 & 12 & & 7 & 4 & 2 & 1 & & Fair \\
\hline 12 & 5 & & 9 & 5 & & & & Good \\
\hline 13 & 4 & & 13 & 2 & 5 & 1 & 2 & Fair \\
\hline 14 & 2 & & 10 & & & & 1 & Fair \\
\hline 15 & 7 & & 6 & 1 & 4 & & & Good \\
\hline 16 & 5 & & 5 & & & 3 & & Good \\
\hline 17 & 4 & & 3 & 4 & & & 2 & Good \\
\hline 18 & 4 & & 6 & 5 & 2 & 1 & 1 & Good \\
\hline 19 & 3 & & 1 & 2 & 1 & 1 & & Good \\
\hline 20 & 4 & & 3 & 1 & 1 & & & Good \\
\hline 21 & 2 & & 1 & 5 & 2 & 3 & & Good \\
\hline 22 & 2 & & 4 & 2 & & 1 & & Good \\
\hline 23 & 3 & & 1 & 2 & & & & Good \\
\hline 24 & 3 & & 4 & 2 & 1 & & & Good \\
\hline 25 & 3 & & 6 & 2 & 1 & 1 & & Good \\
\hline 26 & 3 & & 1 & 3 & & 2 & & Good \\
\hline 27 & 2 & & 9 & 3 & 1 & & & Good \\
\hline 28 & 3 & & 3 & 1 & & 2 & & Good \\
\hline 29 & 3 & & 2 & 3 & & & & Good \\
\hline
\end{tabular}


INFERENCE: Journal of English Language Teaching

Vol. 4, No. 3, December 2021 - March 2022

p-ISSN: 2615-8671

e-ISSN: 2615-868X

\begin{tabular}{|c|c|c|c|c|c|c|c|c|}
\hline 30 & 2 & & 6 & 1 & 2 & 2 & & Fair \\
\hline 31 & 3 & & 1 & 6 & & 3 & & Fair \\
\hline 32 & 2 & & 3 & & 1 & & & Poor \\
\hline 33 & 4 & & 8 & 5 & 1 & 1 & & Good \\
\hline 34 & 4 & & 3 & 2 & 1 & 2 & & Good \\
\hline 35 & 2 & & 2 & 3 & & 2 & 2 & Good \\
\hline 36 & 2 & & 4 & 4 & & 2 & 1 & Good \\
\hline 37 & 2 & & 5 & & & 1 & & Fair \\
\hline 38 & 4 & & 9 & 4 & 2 & 1 & & Good \\
\hline 39 & 5 & & 4 & 1 & 2 & & & Fair \\
\hline 40 & 4 & & 8 & 2 & 2 & 1 & 1 & Good \\
\hline 41 & 3 & & 3 & 3 & 1 & 2 & & Good \\
\hline 42 & 7 & & 6 & 8 & & 1 & & Good \\
\hline 43 & 3 & & 8 & 6 & 3 & 2 & 2 & Good \\
\hline 44 & 4 & & 1 & 1 & & 1 & & Good \\
\hline 45 & 2 & & 4 & 3 & 1 & & & Good \\
\hline 46 & 1 & & 4 & 1 & & & & Less \\
\hline & 172 & 1 & 229 & 121 & 44 & 43 & 14 & 624 \\
\hline
\end{tabular}

Table 3 shows that the 46 students use several types of processes. Those are intensive, existential, possession, material, verbal, mental, and behavioral processes. Moreover, 35 students get a Good level of coherence, nine students get a fair level, and one student gets a lower level. Then one student gets Poor level. Then the data above is presented in the chart below:

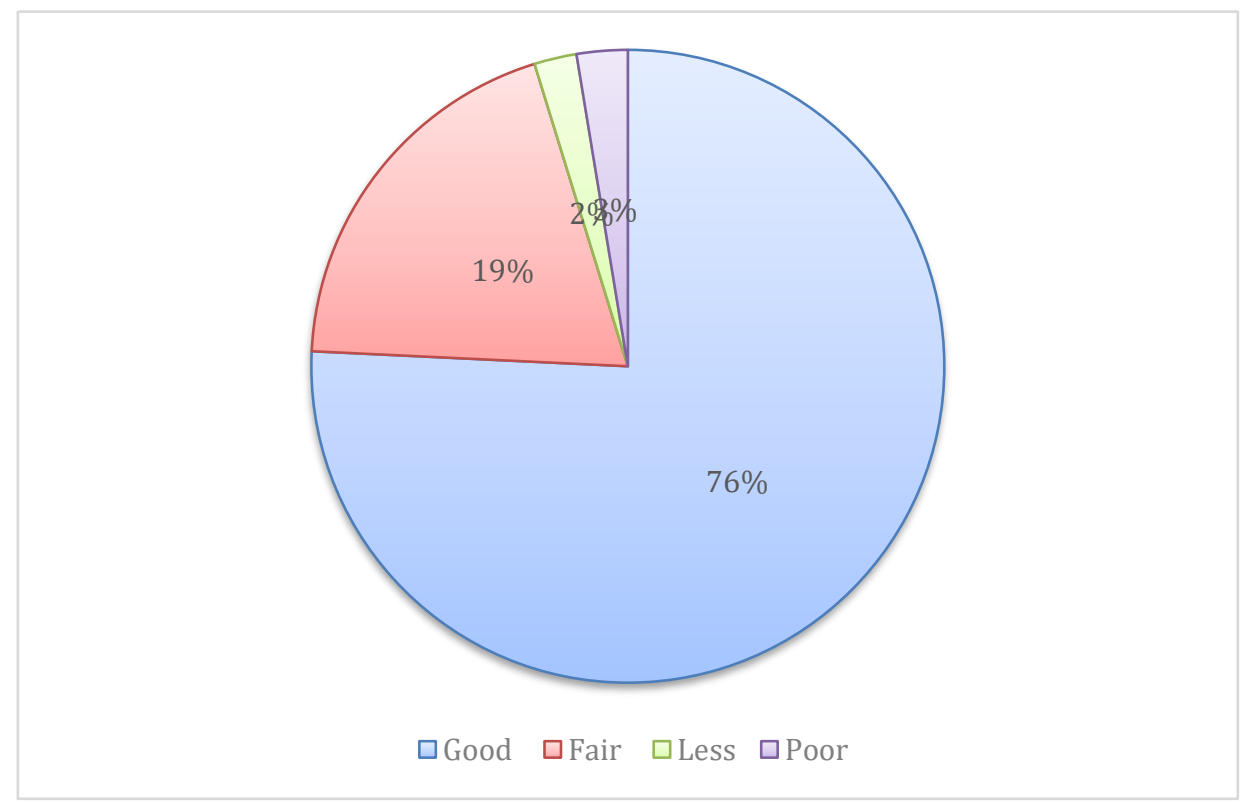

Figure 3. Coherence Level in the Texts

Based on the data analysis, it can be seen that coherence has four levels: good, fair, less, and poor. In the data, $76 \%$ of students got the coherence level at 'Good,' $19 \%$ in Fair, and $2 \%$ in Less. Then the last, poor is at $3 \%$. The example of analyzing coherence level is as follow:

Student 26

Clause $1 \quad$ His real name is Rowan Sebastian Atkinson.

Clause 2 His popular name is Mr. Bean.

Clause $3 \quad H e$ is a funny person

Clause $4 \quad H e$ has short straight black hair.

Clause $5 \quad H e$ has white skin. 


$\begin{array}{ll}\text { Clause } 6 & H e \text { has pointed nose. } \\ \text { Clause } 7 & H e \text { wears green suit with white shirt and red tie. } \\ \text { Clause } 8 & \text { He brings brown doll } \\ \text { Clause } 9 & \text { and sit above the yellow car. } \\ \text { Clause } 10 & \text { He wears black shoes. }\end{array}$

As the thematic progression was analyzed, the researcher found that student 26 uses the constant theme to arrange the text. As the following figure:

Re-iteration or constant Theme

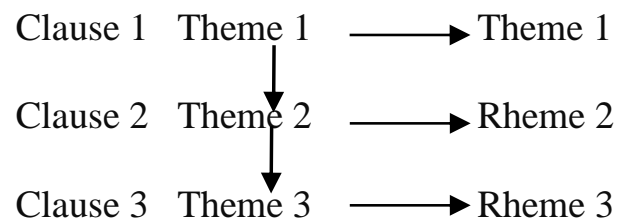

The theme in clause 1 is 'his real name.' It includes an ideational or topical theme, and then clause 2 is 'his popular name' also ideational or topical theme. About nine clauses use a constant theme: the ideational or topical theme. As the criteria of good coherence level are consistent in one passage, student 26 uses the theme to arrange the text. It can be concluded that the text is good level of coherence.

\section{Type of Process Found in the Texts}

The 46 students' descriptive texts are Intensive, existential, possession, material, mental, verbal, and behavioral processes. There are about 172 clauses that use intensive process, one clause uses existential, 229 clauses use material process, 121 clauses use possession process, 44 clauses use mental process, 43 clauses use behavioral process, and 14 clauses use verbal process. This result can be shown in the chart below:

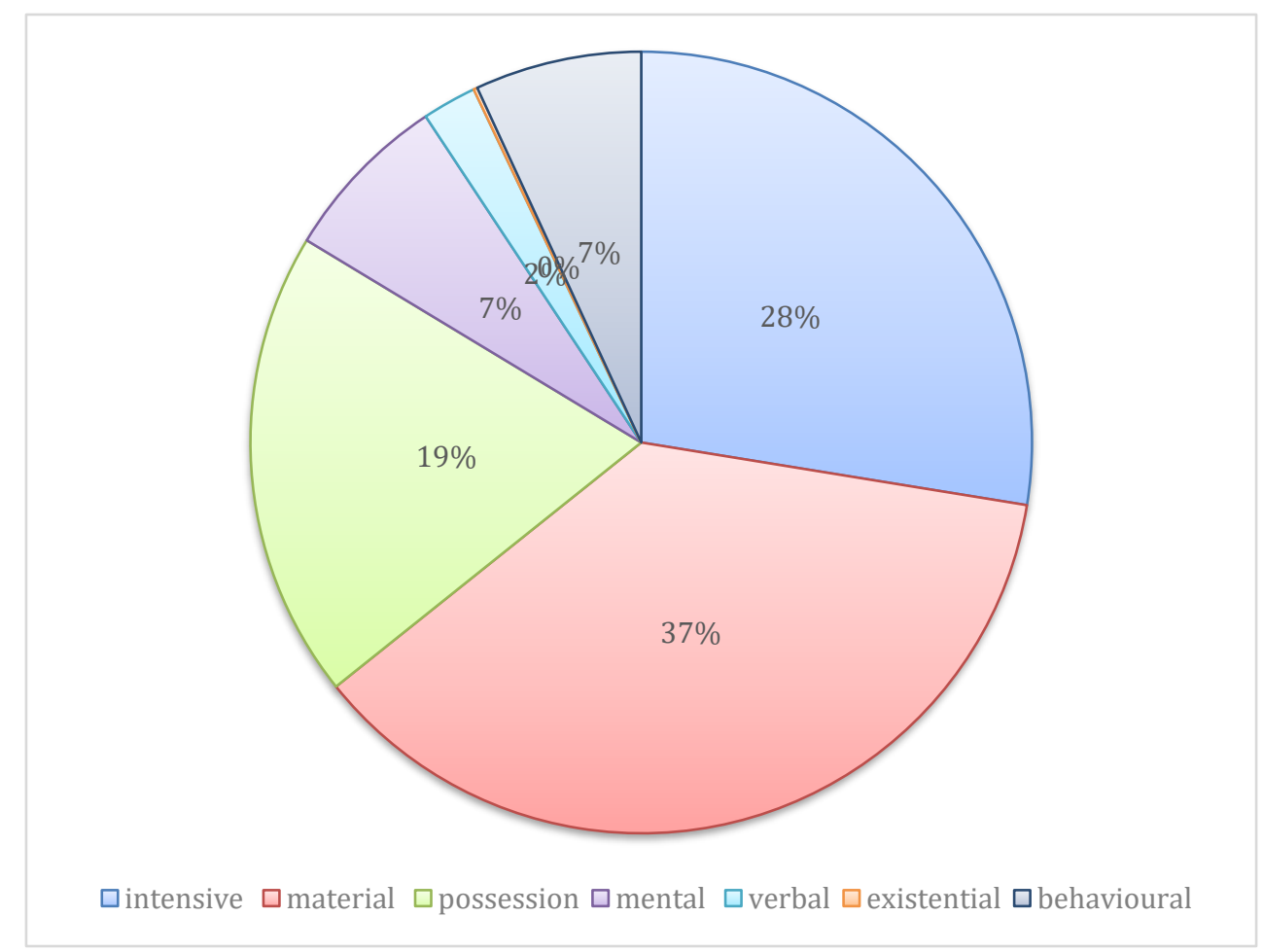

Figure 4. Types of Process that is found in the Texts

Figure 4 shows that students use various processes in expressing and describing Mr. Bean. Those are intensive, material, possession, mental, verbal, existential, and behavioral processes. The intensive process 
INFERENCE: Journal of English Language Teaching

Vol. 4, No. 3, December 2021 - March 2022

p-ISSN: 2615-8671

e-ISSN: $2615-868 \mathrm{X}$

has been used by students and gets a percentage of about $28 \%$, then $37 \%$ is for material process, $19 \%$ is for possession, $7 \%$ is for verbal and behavioral. The last is $1 \%$ for the verbal process.

Result of Analysing Cohesion

a. Grammatical Cohesion

Table 4. Grammatical Cohesion

\begin{tabular}{|c|c|c|}
\hline \multicolumn{3}{|c|}{ Cohesion found in the Texts } \\
\hline Reference & 596 & $69 \%$ \\
\hline Substitution & 0 & $0 \%$ \\
\hline Ellipsis & 0 & $0 \%$ \\
\hline Conjunction & 256 & $31 \%$ \\
\hline Total & 852 & $100 \%$ \\
\hline
\end{tabular}

As the table above shows, $69 \%$ of students use reference markers and $31 \%$ use conjunction in their descriptive texts. Those results can be shown in the chart below:

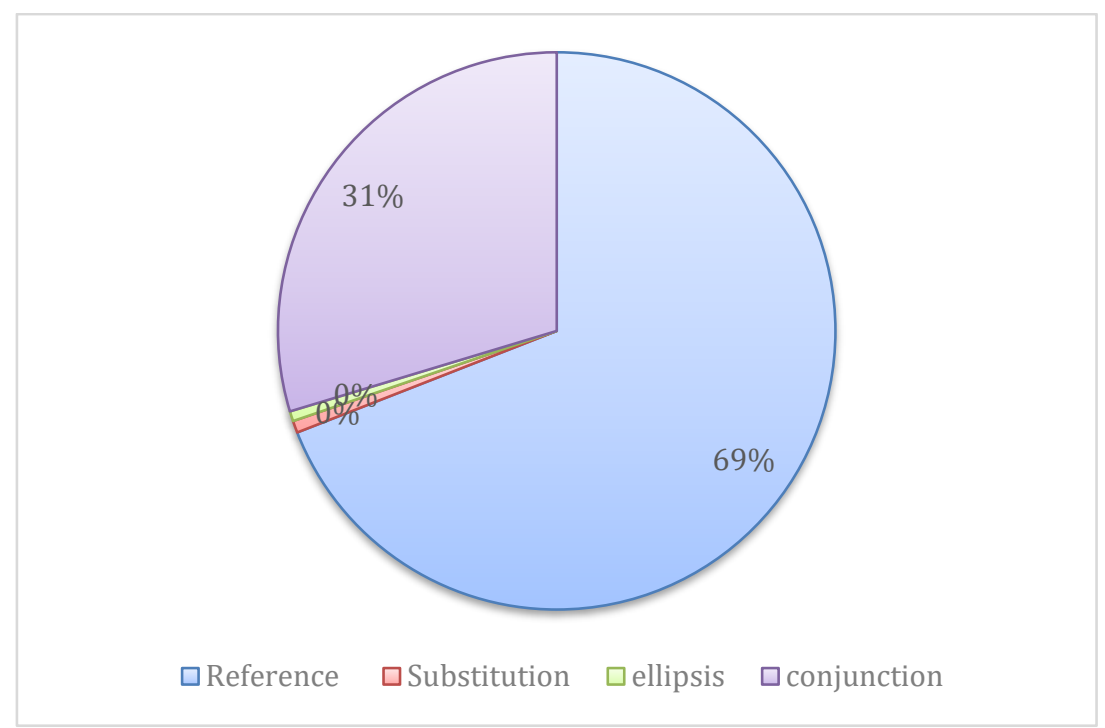

Figure 5. Usage of Grammatical Cohesion in the Texts

The chart above shows that reference markers got the highest percentage for about $69 \%$. Like conjunction, the other markers got the percentage of about $31 \%$, while substitution and ellipsis were not found in the text. It means that the students considered using reference devices than the other device.

b. Lexical Cohesion

There are two types of lexical cohesion, reiteration, and collocation (Halliday and Hasan: 282, 1967). In this research, after analyzing the lexical cohesion, the data found in the text is just in reiteration, especially in repetition. In the reiteration, there are repetition and synonyms. Furthermore, the word that students repeat is common 'Mr. Bean' because they describe the person 'Mr. Bean' and we can see the data shown in the chart below: 


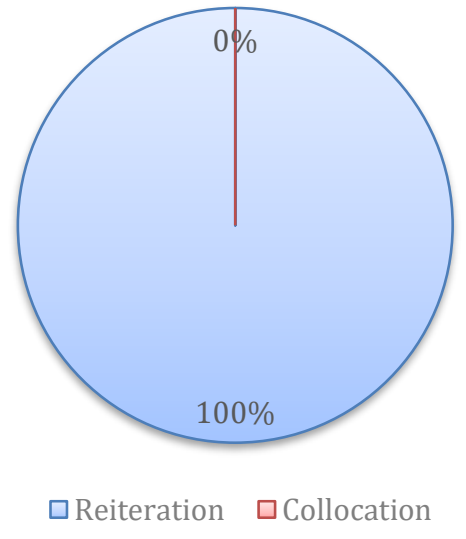

Figure 6. Usage of Lexical Cohesion in the Texts

The chart showed that reiteration got the highest percentage in analyzing lexical cohesion in the texts with $100 \%$. Moreover, the reiteration found in the texts is repetition for about 200 markers. So almost all students use repetition to link the words in the text or tie the entire passage to meaningful and readable texts for the readers.

\section{Conclusions}

Based on the analyzed data, the sample 46 students' Descriptive writing has grown as the stage series in the descriptive text. Those are written within Identification and Description, especially in "describing Mr. Bean." Although many students wrote the Identification just a sentence, the following sentence describes Mr. Bean's physical appearance and clothes. However, some students wrote the Identification fully and completely. Overall, the 46 students have written the descriptive writing and the stage series in descriptive writing. Based on the data analysis, it can be concluded that coherence has fourlevel: good, fair, less, and poor. In the data, $76 \%$ of students got the coherence level is good, and there are $19 \%$ in fair and 2\% in less, then there are 3\% in Poor. Those students should be improved their writing to be better than this writing. In grammatical cohesion, about 852 findings consist of 596 reference markers: personal and demonstrative reference, and 256 conjunction markers in all 46 students' descriptive writing. Besides, in lexical cohesion, there are found 200 repetition markers in 46 students' descriptive writing.

\section{References}

Ary, D., Jacob, L. C., Razavieh, A., \& Sorensen, C. (2010). Introduction to Research in Education. (8 ${ }^{\text {th }}$ Ed.). Wadsworth: Nelson Education, Ltd.

Broughton et al., (2003). Teaching English as a Foreign Language ( $2^{\text {nd }} E d$.). New York: Taylor and Francis e-Library.

Brown, H. D. (2007). Teaching by Principles: An Interactive Approach to Language Pedagogy $\left(3^{\text {rd }}\right.$ Ed). New York: Pearson Education Inc.

Crystal, David. (2003). English as a Global Language. New York: Cambridge University Press

Eggins, S. (2004) An Introduction to Systemic Functional Linguistic. New York: Continuum International Publishing group

Fraenkel, J. R., Wallen, N. E., \& Hyun, H. H. (2011). How to Design and Evaluate Research in Education. New York: McGraw-Hill Companies Inc.

Fairclough, N. (1995) Critical Discourse Analysis: The Critical Study of Language. London: Longman.

Given, et al. (2008) The Sage Encyclopedia of Qualitative Research Method. New Delhi: Sage Publications, Inc.

Halliday, M.A.K 1994. An Introduction to Functional Grammar $\left(3^{\text {rd }}\right.$ Ed). New York: Oxford University Press.

Halliday, M.A.K. \& Hasan, R. (1976) Cohesion in English. London: Longman Group Limited. 
Halliday, M. A. K. \& Matthiessen, C. M. I. M. (2014). An Introduction to Functional Grammar. $\left(4^{\text {th }}\right.$ Ed). London: Routledge.

Harmer, J. (2007). The Practice of English Language Teaching (4 ${ }^{\text {th }}$ Ed.). Harlow: Pearson Longman.

Hogue, Ann. (2008). First Steps in Academic Writing. New York: Pearson Education Inc.

Knapp \& Megan, (2005). Genre, Text, and Grammar. Sydney: University of New South Wales Press.

Lodico, M.G. et al. (2010.) Method in Educational Research: Theory and Practice. New York: Wiley Imprint.

Oshima \& Hogue (2007). An Introduction to Academic Writing. US: Pearson Longman.

Pangestu, et al. (2019) Thematic Progression in Students Descriptive Text (Published Thesis). IKIP Siliwangi.

Paltridge, B. (2006) Discourse Analysis: An Introduction. Britain: Continuum Discourse Series.

Sapir, (1921) Language: An Introduction to the Study of Speech. New York: Hardcourt, Brace.

Schleppegrell, M. J. (2004) The Language of Schooling, A Functional Linguistics Perspective. London: Lawrence Erlbaum Associates Publishers.

Siahaan \& Shinoda. (2008). Generic Text Structure. Yogyakarta: Graha Ilmu.

Tanskanen, S.K. (2006). Collaborating towards Cohesion: Lexical Cohesion in English Discourse. Philadelphia: John Benjamins Publishing Company.

Taylor, M. (1990). Psycholinguistics Learn and Using Language. University of Toronto: Prentice Hall, Inc.

Trzeciak, et al (1995) Study Skill for Academic Writing. Hemel Hempstead: Phoenix Study Series.

Widdowson, H. G. (2004). Text, Context, Pretext: Critical Issues in Discourse Analysis. Oxford: Blackwell Publishing. 